\title{
Culture and the performance of Microfinance Institutions (MFIs)
}

\author{
Tony Ndakoh \\ University of Stellenbosch
}

\begin{abstract}
.
Microfinance has been of strategic importance in the fight against global poverty and the drive towards enhanced sustainable development across the developing world. While interest in Microfinance among global development partners and investors has kept increasing, the industry's performance in reaching key development outcomes has not been even across countries enjoying an active Microfinance presence. An interesting variable hypothesised and empirically proven to explain this discrepancy in Microfinance performance is the formal institutional framework of respective countries relating to elements like laws and governance. Little attention has however been paid to the origin of these formal institutions, namely the informal institutions of a country. This paper investigates the effect of culture (an informal institution) on the performance of Microfinance Institutions (MFIs) using data from 116 MFIs active in 21 countries. Based on the theoretical literature discussing the role of cultural elements such as trust, beliefs, and values, I hypothesize that Microfinance is more successful, both in terms of financial and social objectives, in countries with cultural qualities that give rise to higher inequality, high uncertainty avoidance, low innovation, and low overall trust in others and formal institutions. I test this hypothesis using various culture measures which are linked to measures of financial and social performance of MFIs. The empirical results are generally supportive of my hypothesis, though culture seems to have a stronger explanatory power on social performance measures than it does on financial performance. The results are robust to the use of alternative culture measures, and instrumental variables for the culture measures.
\end{abstract}

Keywords: Credit; Development; Information asymmetry; Institutions; Performance 


\section{Purpose/Objectives}

Several strategies relating to global poverty reduction have been applied across the world for decades. Notable among these is the focus on financial services through the boosting of financial inclusion, the ownership of accounts at formal financial institutions or mobile money service provider. In principle, account ownership should reduce the reliance on cash especially by poor and low income earners, thus permitting them better manage their finances both for consumption and income-smoothing purposes. Better financial management has been of enormous importance in the creation of microenterprises by the poor, women empowerment, child nutrition, health and education, and overall wellbeing at the primary level of society, the household. Between 2011 and 2017, considerable progress has been made on increasing financial inclusion globally. As of 2017 however, $31 \%$ of all adults still remain unbanked, with an overwhelming majority of the unbanked residing in the developing world. International funding for financial inclusion has not relented in its efforts to drive this unbanked percentage lower. A prime channel of these financial inclusion funds is the Microfinance industry. Despite the industry's success in empowering vulnerable populations globally, the relative ease with which this has been attained has varied widely across countries and regions (Masanjala, 2002). Microfinance service delivery strategies that have proven successful in some countries and regions have failed woefully in others, suggesting perhaps that there is no 'one size fits all' rule when it comes to poverty reduction. The literature thus far has identified the formal institutional environment relating to factors like legal systems, property and creditor rights among others as potential determinants of these observed variations in poverty reduction rates. However, little attention has been given to the origin of these formal institutions in empirical research. Williamson (2000) depicts the formal institutional environment of a country as a derivative of its informal institutions like customs and traditions. A failure to consider the effects of culture or informal institutions as a whole in economic analysis has resulted in the failure of supposedly well designed development strategies in the development milieu to achieve equally plausible results across the developing world. In what follows, the need for customization of global development and poverty reduction strategies to specific cultural contexts is looked further into via the potential role of the previously underresearched culture variable on this key channel of development funds, Microfinance.

\section{Methodology}

\subsection{Datasets}

MFI-level balance sheet and income statement data for the performance of MFIs is obtained from the MixMarket ${ }^{1}$ database over the period 2012 - 2016, and currently available in the data catalog of the World Bank. Founded in 2002, the MixMarket contains data on over 2000 Financial Service Providers (FSPs) operating in over 100 countries across the world. MixMarket data has been widely used in Microfinance research as seen in Ahlin et al. (2011), Vanroose \&

\footnotetext{
${ }^{1}$ Accessible at https://www.themix.org/mix-market, consulted 21/03/18
} 


\section{$3^{\text {rd }}$ International Conference on BUSINESS, MANAGEMENT \& ECONOMICS}

6 - 8 MARCH 2020

BUDAPEST, HUNGARY

D'Espallier (2013), Wijesiria et al. (2017), and Elkhuzen et al. (2018) among others. The sample period $(2012-2018)$ is chosen firstly to isolate the effects of the global financial crisis of 2008 -

2010 on risk-taking in the financial services industry, and secondly due to the availability of more complete MFI data on the MIX database, considering that a lot of MFIs in the earlier years of the MIX database's creation only reported partial performance figures. The final dataset comprises 111 MFIs from 21 countries.

Table 1: MFI dataset

\begin{tabular}{|c|c|c|c|c|c|c|c|}
\hline \multicolumn{3}{|c|}{ Panel study period } & \multicolumn{5}{|c|}{$2012-2016(5 y r s)$} \\
\hline \multicolumn{3}{|c|}{ Number of MFIs } & \multicolumn{5}{|l|}{111} \\
\hline \multicolumn{3}{|c|}{ Regions covered } & \multicolumn{5}{|c|}{ Countries } \\
\hline & \multicolumn{2}{|l|}{ SSA } & \multicolumn{2}{|l|}{5} & & & \\
\hline & \multicolumn{2}{|l|}{ EAP/SEA } & \multicolumn{2}{|l|}{6} & & & \\
\hline & \multicolumn{2}{|l|}{ LAC } & \multicolumn{2}{|l|}{7} & & & \\
\hline & \multicolumn{2}{|l|}{ MENA } & \multicolumn{2}{|l|}{3} & & & \\
\hline & \multicolumn{2}{|l|}{ Total } & \multicolumn{2}{|l|}{21} & & & \\
\hline SSA & $\mathbf{N}$ & EAP/SEA & $\mathbf{N}$ & LAC & $\mathbf{N}$ & MENA & $\mathbf{N}$ \\
\hline Burkina Faso & 4 & Bangladesh & 10 & Argentina & 3 & Egypt & 4 \\
\hline Ghana & 6 & China & 3 & Brazil & 7 & Jordan & 3 \\
\hline Nigeria & 6 & India & 11 & Colombia & 10 & Morocco & 3 \\
\hline Tanzania & 2 & Indonesia & 4 & Dominica Rep & 5 & & \\
\hline \multirow[t]{4}{*}{ Zambia } & 2 & Pakistan & 9 & El Salvador & 2 & & \\
\hline & & Philippines & 7 & Mexico & 7 & & \\
\hline & & & & Peru & 8 & & \\
\hline & \multicolumn{2}{|l|}{20} & \multicolumn{2}{|l|}{44} & 42 & & 10 \\
\hline
\end{tabular}

Notes: This table indicates countries represented in the study. Due to incomplete data, only 6 SSA countries could be included.

Culture has historically been measured via surveys and experiments. A number of survey-based datasets on cultural measures exist. Among these are the Hofstede (1983) and Schwartz (1994) cultural dimensions, GLOBE project of House et al. (2004), and the World Values Survey (1980 -2014). Hofstede and GLOBE databases are used extensively in this research.

Hofstede's database results from a survey of IBM employees working in 72 national subsidiaries with different occupations as well as languages first in the late 1960s and early 1970s (Hofstede et al., 2010 pp. 29 - 30; Ashraf \& Arshad, 2017). Hofstede was able to replicate his study in the course of the 1970s with non-IBM executives from different countries. Using factor analysis, he came out with four cultural dimensions revealing common problems identified by the employees, but with solutions differing from country to country, in: social inequality, including the relationship with authority; the relationship between the individual and the group; concepts of masculinity and femininity: the social and emotional implications of having been born as a boy or a girl; and ways of dealing with uncertainty and ambiguity, which turned out to be related to 


\section{$3^{\text {rd }}$ International Conference on BUSINESS, MANAGEMENT \& ECONOMICS}

6 - 8 MARCH 2020

BUDAPEST, HUNGARY

the control of aggression and the expression of emotions (Hofstede et al., 2010, pp. 30). Each country has a score on a 0 to 100 scale for each dimension with increasing scores implying higher values on the variable measured.

\subsection{Model, variables and estimation}

\subsubsection{Model and estimation}

In assessing the effects of culture on the performance of MFIs in this panel study, the following econometric model is used:

$$
\text { Perf }_{\mathrm{ijt}}=\alpha+\beta \text { Culture }_{\mathrm{jt}}+\gamma \mathrm{M}_{\mathrm{it}}+\lambda \mathrm{X}_{\mathrm{jt}}+\theta \mathrm{Z}_{\mathrm{jt}}+\epsilon_{\mathrm{ijt}}
$$

where Perf $\mathrm{ijt}_{\mathrm{jt}}=$ performance of institution $i$ in country $j$ at time $t$, given by ROA, OSS, NAB, $\mathrm{NFB}$, and ALB; the coefficients $\beta, \gamma, \lambda$, and $\delta$ are XY matrices for the respective explanatory variables and controls of the time-invariant national cultural dimensions, Microfinance-specific $(\mathrm{M})$, Macroeconomic-specific $(\mathrm{X})$, and formal institution-specific $(\mathrm{Z})$ variables; $\alpha$ is the matrix of intercepts, while $\epsilon_{\mathrm{ijt}}$ represents the composite error term comprising $v_{\mathrm{it}}$, the unobserved MFIspecific attributes which may not be captured in the model but which affect performance like geographic location, and $\mathrm{u}_{\mathrm{ijt}}$ is the idiosyncratic error term. A Generalised Least Squares (GLS) estimation procedure is used here. The GLS encompasses fixed and random effects estimators. The random effects estimator is applied, the main reason being that Culture is time-invariant, and thus will not be partialled out in the estimations as does the fixed effects model which completely omits time-invariant variables.

\subsubsection{Variables}

Table 2 presents and describes respective variables used in this study.

Table 2: Variables and definitions

\begin{tabular}{|c|c|c|c|}
\hline Variable & Notation & Description/Computation where applicable & Data source \\
\hline \multicolumn{4}{|l|}{ A. Dependent variables } \\
\hline Return on assets & ROA & Net income/Total assets & MIX \\
\hline Operational self-sufficiency & OSS & Financial revenue/(Financial expense + Operating expense) & MIX \\
\hline Number of active borrowers & NAB & Headcount of the number of active borrowers & MIX \\
\hline Number of female borrowers & NFB & Headcount of the number of female borrowers & MIX \\
\hline Average loan balance & ALB & Total loans/Number of active borrowers & MIX \\
\hline \multicolumn{4}{|c|}{ B. Explanatory variables: Culture } \\
\hline Power distance & PDI & $\begin{array}{l}\text { Composite index ranging from } 0 \text { to } 100 \text {, higher score meaning } \\
\text { more authoritarian and bureaucratic structures }\end{array}$ & Hofstede's dimensions \\
\hline Individualism/Collectivism & IDV & $\begin{array}{l}\text { Composite index ranging from } 0 \text { to } 100 \text {, higher score meaning } \\
\text { more individualistic societies }\end{array}$ & Hofstede's dimensions \\
\hline Uncertainty avoidance & UAI & $\begin{array}{l}\text { Composite index ranging from } 0 \text { to } 100 \text {, higher score meaning a } \\
\text { higher preference for certainty }\end{array}$ & Hofstede's dimensions \\
\hline Masculinity/Femininity & MAS & $\begin{array}{l}\text { Composite index ranging from } 0 \text { to } 100 \text {, higher score meaning a } \\
\text { more masculine society }\end{array}$ & Hofstede's dimensions \\
\hline
\end{tabular}




\section{$3^{\text {rd }}$ International Conference on BUSINESS, MANAGEMENT \& ECONOMICS}

\begin{tabular}{|c|c|c|c|}
\hline \multirow{2}{*}{$\begin{array}{l}\text { Long term orientation } \\
\text { Indulgence/Restraint }\end{array}$} & \multirow{2}{*}{$\begin{array}{l}\text { LTO } \\
\text { IND }\end{array}$} & $\begin{array}{l}\text { Composite index ranging from } 0 \text { to } 100 \text {, higher score meaning a } \\
\text { more future-oriented society }\end{array}$ & \multirow{2}{*}{$\begin{array}{l}\text { Hofstede's dimensions } \\
\text { Hofstede's dimensions }\end{array}$} \\
\hline & & $\begin{array}{l}\text { Composite index ranging from } 0 \text { to } 100 \text {, higher score meaning a } \\
\text { freer or less socially restricted society }\end{array}$ & \\
\hline \multicolumn{4}{|l|}{ C. Control variables } \\
\hline $\begin{array}{l}\text { Formal } \\
\text { institutions }\end{array}$ & & & \\
\hline Political stability & POLSTAB & $\begin{array}{l}\text { Composite index ranging from }-4 \text { to } 4 \text {, higher score meaning a } \\
\text { more politically stable country }\end{array}$ & World Governance Indicators \\
\hline Regulatory quality & REGQUAL & $\begin{array}{l}\text { Composite index ranging from }-4 \text { to } 4 \text {, higher score meaning } \\
\text { better regulatory quality }\end{array}$ & World Governance Indicators \\
\hline Legal origin & LGOR & $\begin{array}{l}\text { Categorical variable indicating the origin of a country's legal } \\
\text { system (Common of civil law) }\end{array}$ & $\begin{array}{l}\text { A.Shleifer Havard webpages } \\
\text { (scholar.havard.edu/shleifer) }\end{array}$ \\
\hline \multirow[t]{2}{*}{$\begin{array}{l}\text { Time to start business } \\
\text { Time to enforce contracts }\end{array}$} & TSTARTBUS & $\begin{array}{l}\text { Time in days required to start a business with necessary legal } \\
\text { paperwork }\end{array}$ & World Development Indicators \\
\hline & TCENFORCE & Time in days required to enforce contracts & World Development Indicators \\
\hline \multicolumn{4}{|l|}{ II. MFI-specific } \\
\hline Age & AGE & Time in years the MFI has existed or been in operation & MIX \\
\hline Size & SIZE & Total assets in millions of US\$ of the MFI & MIX \\
\hline Debt/Equity (funding structure) & DEBTEQ & Ratio of MFI's debt to its equity capital & MIX \\
\hline Portfolio at risk (asset quality) & PAR30 & Outstanding loans $>30$ days/adjusted Gross Loan Portfolio (\%) & MIX \\
\hline Operating efficiency & OPEFF & Operating expenses/Gross Loan Portfolio (\%) & MIX \\
\hline Asset structure & GLPTA & Gross loans portfolio/Total assets (\%) & MIX \\
\hline \multicolumn{4}{|l|}{ III. Macroeconomic } \\
\hline National wealth & GDPPC & Gross domestic product per capita & World Development Indicators \\
\hline Structure of economy & AMSGDP & Agriculture, Manufacturing, \& Services respectively/GDP (\%) & World Development Indicators \\
\hline Price stability & INFL & Index, consumer prices & World Development Indicators \\
\hline Financial structure & DOMCRPVT & Domestic credit to the private sector/GDP (\%) & World Development Indicators \\
\hline Openness to trade & FDIGDP & Foreign Direct Investment/GDP (\%) & World Development Indicators \\
\hline Financial access & ACCTOWN & $\%$ of population with accounts at formal financial institutions & World Development Indicators \\
\hline
\end{tabular}

Source: Author, 2018

\section{Estimation results and discussion}

Table 3 reports the regression results for the effect of culture on both financial and social performances of MFIs. Robust standard errors are used to cater for potential heteroskedasticity. 
Table 3: Effects of culture on financial and social performance of MFIs

\begin{tabular}{|c|c|c|c|c|c|}
\hline VARIABLES & roa & oss & ln_nab & ln_nfb & ln_alb \\
\hline \multicolumn{6}{|c|}{ Main variable: Culture } \\
\hline \multirow[t]{2}{*}{ pdi } & $0.00128 *$ & 0.00306 & $0.0237 * *$ & $0.0420 * * *$ & -0.0162 \\
\hline & $(0.000748)$ & $(0.00298)$ & $(0.0114)$ & $(0.0143)$ & $(0.0105)$ \\
\hline \multirow[t]{2}{*}{$\mathrm{idv}$} & -0.000433 & -0.00129 & $-0.0180 * *$ & $-0.0195 *$ & $0.0138 * *$ \\
\hline & $(0.000461)$ & $(0.00209)$ & $(0.00768)$ & $(0.0104)$ & $(0.00695)$ \\
\hline \multirow[t]{2}{*}{ mas } & 0.00132 & -0.00193 & $0.0177 *$ & 0.0153 & $-0.0265 * * *$ \\
\hline & $(0.00103)$ & $(0.00234)$ & $(0.0105)$ & $(0.0132)$ & $(0.00986)$ \\
\hline \multirow[t]{2}{*}{ uai } & 0.000316 & -0.000166 & -0.00585 & -0.00984 & 0.000424 \\
\hline & $(0.000558)$ & $(0.00151)$ & $(0.00661)$ & $(0.00801)$ & $(0.00636)$ \\
\hline \multirow[t]{2}{*}{ lto } & $-5.28 \mathrm{e}-05$ & $-0.00284 *$ & 0.00912 & 0.0127 & -0.00847 \\
\hline & $(0.000497)$ & $(0.00172)$ & $(0.00647)$ & $(0.00839)$ & $(0.00697)$ \\
\hline \multirow[t]{2}{*}{ ind } & 0.000178 & -0.00132 & $-0.00854^{*}$ & -0.00860 & $0.0106^{* *}$ \\
\hline & $(0.000308)$ & $(0.00127)$ & $(0.00492)$ & $(0.00594)$ & $(0.00474)$ \\
\hline \multicolumn{6}{|c|}{ MFI-specific controls } \\
\hline \multirow[t]{3}{*}{ age } & -0.000526 & -0.000517 & -0.00127 & 0.00166 & 0.00624 \\
\hline & $(0.000527)$ & $(0.00164)$ & $(0.0135)$ & $(0.0164)$ & $(0.00800)$ \\
\hline & $-0.109 * * *$ & $-0.262 * * *$ & $0.530 * *$ & $0.972 * * *$ & $-0.395^{*}$ \\
\hline & $(0.0175)$ & $(0.0560)$ & $(0.268)$ & $(0.323)$ & $(0.210)$ \\
\hline \multirow[t]{2}{*}{ dumcoop } & $-0.139 * * *$ & $-0.339 * * *$ & -0.204 & 0.126 & 0.230 \\
\hline & $(0.0261)$ & $(0.0779)$ & $(0.393)$ & $(0.460)$ & $(0.362)$ \\
\hline \multirow[t]{2}{*}{ dumngo } & $-0.0681 * * *$ & $-0.148 * * *$ & $0.490 * *$ & $0.985 * * *$ & $-0.459 * *$ \\
\hline & $(0.0163)$ & $(0.0494)$ & $(0.219)$ & $(0.277)$ & $(0.218)$ \\
\hline \multirow[t]{2}{*}{ par30 } & $-0.415^{* * *}$ & $-0.877 * * *$ & $-1.687 *$ & -1.303 & 0.223 \\
\hline & $(0.115)$ & $(0.173)$ & $(0.872)$ & $(1.040)$ & $(0.425)$ \\
\hline \multirow[t]{2}{*}{ ln_size } & -0.00175 & $0.0357 * * *$ & $0.680 * * *$ & $0.650 * * *$ & $0.193 * * *$ \\
\hline & $(0.00459)$ & $(0.0102)$ & $(0.126)$ & $(0.136)$ & $(0.0372)$ \\
\hline \multirow[t]{2}{*}{ debt_eq } & $-0.00235 * * *$ & $-0.00559 * * *$ & 0.00543 & 0.00495 & 0.000209 \\
\hline & $(0.000671)$ & $(0.000684)$ & $(0.00596)$ & $(0.00635)$ & $(0.00150)$ \\
\hline \multirow[t]{2}{*}{ op_eff } & $-0.372 * * *$ & $-0.673 * * *$ & -0.575 & -0.500 & $-0.289 *$ \\
\hline & $(0.0864)$ & $(0.0696)$ & $(0.385)$ & $(0.397)$ & $(0.161)$ \\
\hline \multirow[t]{2}{*}{ glp_ta } & -0.0213 & 0.0636 & $0.725 * * *$ & $0.779 * * *$ & $0.297 * * *$ \\
\hline & $(0.0278)$ & $(0.0431)$ & $(0.241)$ & $(0.265)$ & $(0.0719)$ \\
\hline \multicolumn{6}{|c|}{ Formal institution controls } \\
\hline \multirow[t]{2}{*}{ pol_stab } & 0.00147 & -0.0350 & 0.0503 & $0.182 *$ & -0.0678 \\
\hline & $(0.00777)$ & $(0.0222)$ & $(0.0717)$ & $(0.102)$ & $(0.0528)$ \\
\hline \multirow[t]{2}{*}{ reg_qual } & 0.00594 & 0.0162 & -0.184 & -0.229 & 0.0471 \\
\hline & $(0.0140)$ & $(0.0464)$ & $(0.166)$ & $(0.207)$ & $(0.122)$ \\
\hline \multirow[t]{2}{*}{ dumlegor } & 0.00889 & 0.00372 & 0.0871 & 0.162 & -0.0735 \\
\hline & $(0.0179)$ & $(0.0689)$ & $(0.272)$ & $(0.337)$ & $(0.214)$ \\
\hline
\end{tabular}




\begin{tabular}{|c|c|c|c|c|c|}
\hline tstart_bus & 0.000404 & $0.00146 *$ & -0.00406 & -0.00553 & 0.00137 \\
\hline tc_enforce & $\begin{array}{l}(0.000408) \\
-4.10 \mathrm{e}-05^{* *} \\
(2.00 \mathrm{e}-05)\end{array}$ & $\begin{array}{l}(0.000827) \\
1.84 \mathrm{e}-05 \\
(5.22 \mathrm{e}-05)\end{array}$ & $\begin{array}{l}(0.00384) \\
-0.000307 \\
(0.000241)\end{array}$ & $\begin{array}{l}(0.00421) \\
-0.000154 \\
(0.000294)\end{array}$ & $\begin{array}{l}(0.00183) \\
0.000262 \\
(0.000218)\end{array}$ \\
\hline \multicolumn{6}{|c|}{ Macroeconomic controls } \\
\hline lngdppc & $\begin{array}{l}0.0266^{* *} \\
(0.0109)\end{array}$ & $\begin{array}{l}0.0872 * * \\
(0.0343)\end{array}$ & $\begin{array}{l}-0.161 \\
(0.180)\end{array}$ & $\begin{array}{l}-0.0197 \\
(0.207)\end{array}$ & $\begin{array}{l}0.447 * * * \\
(0.120)\end{array}$ \\
\hline mft_gdp & $\begin{array}{l}0.0462 \\
(0.178)\end{array}$ & $\begin{array}{l}0.321 \\
(0.737)\end{array}$ & $\begin{array}{l}1.280 \\
(1.919)\end{array}$ & $\begin{array}{l}1.709 \\
(2.367)\end{array}$ & $\begin{array}{l}-2.643 * * \\
(1.337)\end{array}$ \\
\hline infl & $\begin{array}{l}0.160 \\
(0.104)\end{array}$ & $\begin{array}{l}0.194 \\
(0.181)\end{array}$ & $\begin{array}{l}1.729 * * \\
(0.839)\end{array}$ & $\begin{array}{l}2.341 * * \\
(1.021)\end{array}$ & $\begin{array}{l}-1.681 * * * \\
(0.468)\end{array}$ \\
\hline domcrpvt_gdp & $\begin{array}{l}-0.104 * * * \\
(0.0378)\end{array}$ & $\begin{array}{l}-0.415^{* * *} \\
(0.130)\end{array}$ & $\begin{array}{l}0.790 * * \\
(0.369)\end{array}$ & $\begin{array}{l}0.792 * \\
(0.457)\end{array}$ & $\begin{array}{l}-0.733 * * \\
(0.314)\end{array}$ \\
\hline fdi_gdp & $\begin{array}{l}0.306^{*} \\
(0.159)\end{array}$ & $\begin{array}{l}0.344 \\
(0.333)\end{array}$ & $\begin{array}{l}-1.345 \\
(0.935)\end{array}$ & $\begin{array}{l}-2.623 * * * \\
(0.786)\end{array}$ & $\begin{array}{l}0.744 \\
(1.137)\end{array}$ \\
\hline acct_own & $\begin{array}{l}-0.00725 \\
(0.0354)\end{array}$ & $\begin{array}{l}0.0436 \\
(0.0955)\end{array}$ & $\begin{array}{l}-0.173 \\
(0.372)\end{array}$ & $\begin{array}{l}-0.573 \\
(0.448)\end{array}$ & $\begin{array}{l}-0.367^{*} \\
(0.211)\end{array}$ \\
\hline Constant & $\begin{array}{l}-0.0428 \\
(0.124)\end{array}$ & $\begin{array}{l}0.353 \\
(0.325)\end{array}$ & $\begin{array}{l}-2.221 \\
(1.745)\end{array}$ & $\begin{array}{l}-4.783 * * \\
(2.047)\end{array}$ & $\begin{array}{l}1.845 \\
(1.397)\end{array}$ \\
\hline \multicolumn{6}{|l|}{ Statistics } \\
\hline Observations & 548 & 555 & 553 & 539 & 553 \\
\hline Groups & 111 & 111 & 111 & 111 & 111 \\
\hline R-squared: within & 0.4321 & 0.3018 & 0.6119 & 0.4742 & 0.4725 \\
\hline between & 0.6220 & 0.5338 & 0.8219 & 0.7249 & 0.5898 \\
\hline overall & 0.5385 & 0.4749 & 0.8124 & 0.7153 & 0.5861 \\
\hline Wald $\chi^{2}$ & 249.20 & 419.60 & 1978.48 & 1253.28 & 648.62 \\
\hline
\end{tabular}

Notes: Regression results for the effect of culture on financial and social performance of MFIs are reported in this table. The figures in parentheses represent Standard errors (SE). Robust standard errors are used here to cater for heteroskedasticity. The first two models represent financial performance, while the last three represent social performance. In all models, controls are made for MFI-specific, formal institutional framework, and macroeconomic environment variables. ***, **, and * represent statistical significance at $1 \%, 5 \%$ and $10 \%$ levels respectively.

Regression results presented in Table 3 above indicate that Microfinance reaches fewer active and female borrowers in more individualistic cultures, cultures of higher uncertainty avoidance, and more indulgent cultures. Meanwhile, Microfinance reaches more active and female borrowers in cultures which accept that power be distributed unequally or high power distance cultures, more masculine cultures, and more long term oriented cultures (though not statistically significant here). These findings are supported by the theoretical propositions in this research. To the extent that culture conditions human behaviour, societal roles are indirectly defined and crafted by cultural patterns. I thus find strong support for our hypotheses H1, H2, H3, and H6 relating respectively to power distance, masculinity/femininity, uncertainty avoidance, and indulgence/restraint, particularly for the social performance measures. With the exception of power distance, the effects of culture on financial performance are statistically less significant. Power distance 
Microfinance in high power distance cultures achieves high social performance on all three measures (number of active borrowers, number of female borrowers, and average loan balance). This strongly supports the hypothesis $\mathrm{H} 1$ for the power distance measure presented in Table 1 above. High power distance signals potentially higher inequality, thus creating a potentially larger base of traditional MFI clients, poor and low income earners. In addition, high power distance stifles innovation as people will be less willing, for fear of authority to find better ways of doing things. People in such countries may thus end up doing the same old things in the same old ways, creating micro and small enterprises which represent a key client base of MFIs. In the SSA sub-sample, power distance figures range from 60 in Zambia through 70 in Tanzania and Burkina Faso, and 80 in Ghana and Nigeria, to 85 in Mozambique. MFIs in Mozambique are thus expected to perform better socially than those in Zambia, and even better in the Philippines (PDI of 94) than in Argentina (PDI of 49). Meanwhile due to the sheer number of clients reached and related transaction costs determined by the formal institutional environment, Microfinance could achieve high financial performance in high power distance cultures, as indicated by the positive though less statistically significant results on the power distance culture measure.

Individualism/Collectivism

In more individualistic cultures, Microfinance reaches fewer clients and grants bigger loans implying lower social performance, strongly supporting hypothesis $\mathrm{H} 2$ in this study. Being one of the more frequently used cultural measures, this individualism finding contradicts sharply the findings of Postelnicu \& Hermes (2015) where social performance is found to be higher in more individualistic cultures. In more individualistic cultures, there may be lower societal trust, and working in groups poses a particular challenge given behavioural patterns prompted by this low trust. MFIs, particularly of the NGO and Cooperative types should in theory find it particularly difficult to thrive in such individualistic cultures. On the whole, MFIs can grant bigger loans in more individualistic cultures, as both the MFIs and their clients are open to take upon higher risk. By granting bigger loans, MFIs should be able to achieve higher financial performance in more individualistic cultures. Berggren \& Burzynska (2014) however suggest that MFIs in more individualistic cultures will achieve lower financial performance although they may be able to grant bigger loans as suggested by the negative though statistically insignificant coefficients here for the financial performance measures. This they explain is because MFIs in more individualistic cultures usually end up with higher cost burdens as they will find it more difficult to leverage the advantages present in collectivist cultures like the use of soft information to reduce information asymmetry. Based on the individualism measure thus, MFIs in Columbia with an individualism index of 13 should in principle reach more active and female borrowers and grant overall smaller loans than MFIs in more individualistic India with an individualism index of 48. Likewise MFIs in Zambia with an individualism index of 35 should reach fewer active and female borrowers and grant bigger loans than MFIs in less individualistic Tanzania with an individualism index of 25. In more collectivist cultures like Burkina Faso, Ghana, and Mozambique with respective individualism indices of 15 , Microfinance should reach more clients including women, and grant smaller loans.

Masculinity/Femininity 
In more masculine cultures, formal employment opportunities or paid jobs, and big businesses are reserved for men. In developing settings however, these opportunities are few thus leaving a big proportion of the population to cater for themselves. This excluded population then engages in microenterprise activities, whose owners make up the traditional clientele of MFIs. Additionally with men taking up the few paid jobs, women are left to cater for the household and take upon the less lucrative economic activities in society. Thus Microfinance reaches more active borrowers in more masculine societies, including more women. Strong support is thus found for the hypothesis $\mathrm{H} 3$ in Table 1 above in relation to the Masculinity/Femininity measure. Microfinance will thus be expected, based on these findings to reach more active borrowers including women in Mexico with a Masculinity index of 69 than it would in Chile with a low Masculinity index of 28, and in Nigeria and Burkina Faso with respective masculinity indices of 60 and 50 than Mozambique and Ghana with respective masculinity indices of 38 and 40. Because Microfinance targets these often less lucrative economic activity operators who own smaller businesses, it can only serve them via smaller loans, explaining the significant negative coefficient on the masculinity measure for average loan balance. Besides with a bigger number of active borrowers, their loan needs can only be met with several small loans. With smaller loans however, it may prove a more arduous task for MFIs to meet their financial objectives in more masculine cultures, especially when informal institutions are weaker suggesting transaction costs may be higher. On a whole therefore, MFIs achieve better social performance than they do financial performance in more masculine cultures, confirming the hypothesis in Table 1.

Uncertainty avoidance

A similar logic to individualism applies for Uncertainty avoidance - due to higher risk taking in low uncertainty avoidance cultures like India with an index of 40, MFIs should be able to grant bigger loans, but may reach fewer active and female borrowers as they may end up targeting a richer clientele. It may thus not be uncommon on cultural grounds to find a fair number of shareholder-owned or commercial MFIs in more individualistic and low uncertainty avoidance India, than in very high uncertainty avoidance cultures like El Salvador and Peru with respective uncertainty avoidance indices of 94 and 87, or Ghana with an index of 65 . The findings on uncertainty avoidance measure in this study however are statistically insignificant across all dependent variables. Additionally, the coefficient signs do not all conform to those hypothesised for the social performance measures in hypothesis $\mathrm{H} 4$ above. The findings on this cultural measure therefore remain quite inconclusive, as we do not find support for this in the resulting regression coefficients.

Long term orientation

More long-term oriented societies take active steps to reduce poverty and inequality, and by so doing design programs that target poorer and more vulnerable groups like women who make up the traditional clientele of Microfinance. Thus Microfinance again achieves higher social performance in more long-term oriented cultures. This finding is in line with that of Manos \& Tsytrinbaum (2014) who use a similar measure, future orientation from the GLOBE database in their analysis. In addition, people in such cultures plan for the long term, and are thus more likely to take upon bigger risks and invest or create more sustainable enterprises. Higher risk may warrant higher monitoring costs, which presents a particular problem for MFIs especially in low 
trust societies. With these higher costs, it may be more difficult for MFIs to be operationally selfsustaining. This however is in contrast with the hypothesis H5 developed for the Long term orientation measure, where Microfinance was expected to perform well on both financial and social measures in more long term oriented cultures, both via granting bigger loans in these higher risk-taking cultures, and reaching more vulnerable people due to the inclusive nature of their policies respectively.

Indulgence/restraint

In high indulgent cultures like Mexico with an indulgence index of 97, people enjoy the things of life and place fewer restrictions on human pleasures and needs. Microfinance reaches fewer active and female borrowers in such societies as people generally will be less willing to conform to the strict needs and requirements of financial or loan contracts. This is additionally prompted by high uncertainty avoidance in a society like Mexico (uncertainty avoidance index of 82). Thus people on a whole in such high indulgent cultures will be less willing to enter into financial contracts, than those in low indulgence cultures like Pakistan (indulgence index of 0), Egypt (4), Burkina Faso (18), and Bangladesh (20). Microfinance should thus reach more active and female borrowers in the latter group of countries, and it will do so with low average loan balances, in contrast to high indulgent countries like Mexico, Nigeria (84), and Mozambique (80) where people are less restricted or more happiness-driven. Financial performance in this case presents mixed results as suggested by the coefficients in the regressions here, and in line with the hypothesis $\mathrm{H6}$ for the indulgence/restraint cultural measure. In reaching fewer clients, Microfinance can grant bigger loans, and depending on the level of transaction and related operation costs determined both by culture and the formal institutional environment, MFIs can perform either positively or negatively on financial measures.

\section{Robustness: Results using an alternative dataset for the cultural dimensions}

To quell this validity debate of Hofstede's database, one way out is to use a different culture database, preferably a more recent one and conduct similar regressions. The GLOBE database serves this purpose perfectly. This database, developed by House et al. (2004) comprises nine cultural dimensions, some very similar to those of Hofstede with respect to their definition and measurement. These include Power distance, In-Group Collectivism, Assertiveness, Uncertainty avoidance, Future orientation, Institutional Collectivism, Performance Orientation, Humane orientation, and Gender Egalitarianism. The first five GLOBE measures above are most closely related to the first five of Hofstede's cultural dimensions. Table 5 reports the regression results for the effect of culture measured via the GLOBE cultural values on performance of MFIs. 
Table 4: Culture and MFI performance, GLOBE cultural dimensions

\begin{tabular}{|c|c|c|c|c|c|}
\hline & (1) & (2) & (3) & (4) & $(5)$ \\
\hline VARIABLES & roa & oss & ln_nab & ln_nfb & ln_alb \\
\hline \multicolumn{6}{|c|}{ Main variable: Culture } \\
\hline \multirow[t]{2}{*}{ pwr_dist } & -0.0400 & 0.567 & 1.253 & $2.779 * *$ & -0.356 \\
\hline & $(0.123)$ & $(0.995)$ & $(0.894)$ & $(1.097)$ & $(0.766)$ \\
\hline \multirow[t]{2}{*}{ ingrp_coll } & -0.0767 & 0.454 & 0.0366 & 0.554 & 0.166 \\
\hline & $(0.0764)$ & $(0.807)$ & $(0.547)$ & $(0.754)$ & $(0.492)$ \\
\hline \multirow[t]{2}{*}{ assert } & 0.0345 & 0.132 & $1.159 * * *$ & $1.884 * * *$ & $-0.865 * * *$ \\
\hline & $(0.0615)$ & $(0.188)$ & $(0.293)$ & $(0.364)$ & $(0.282)$ \\
\hline \multirow[t]{2}{*}{ unc_avoi } & 0.147 & -0.395 & $2.388 * * *$ & $3.843 * * *$ & $-2.145 * * *$ \\
\hline & $(0.0945)$ & $(0.597)$ & $(0.583)$ & $(1.169)$ & $(0.579)$ \\
\hline \multirow[t]{2}{*}{ fut_ori } & -0.221 & -2.840 & $-20.88 * * *$ & $-24.98 * * *$ & $16.17 * * *$ \\
\hline & $(0.581)$ & $(1.834)$ & $(3.043)$ & $(3.492)$ & $(2.370)$ \\
\hline \multirow[t]{2}{*}{ ins_coll } & -0.142 & -0.0461 & $-2.485 * * *$ & $-1.743^{*}$ & $2.013 * * *$ \\
\hline & $(0.109)$ & $(0.771)$ & $(0.877)$ & $(0.996)$ & $(0.634)$ \\
\hline \multirow[t]{2}{*}{ hum_ori } & 0.0727 & -0.111 & $1.512^{* *}$ & $1.502 * *$ & -0.822 \\
\hline & $(0.0680)$ & $(0.233)$ & $(0.600)$ & $(0.693)$ & $(0.560)$ \\
\hline \multirow[t]{2}{*}{ perf_ori } & 0.249 & 1.578 & $10.60 * * *$ & $10.98 * * *$ & $-7.945 * * *$ \\
\hline & $(0.332)$ & $(1.061)$ & $(2.091)$ & $(2.462)$ & $(1.294)$ \\
\hline \multirow[t]{2}{*}{ gen_egal } & -0.0585 & -0.505 & $-2.379 * * *$ & $-2.049 * *$ & $2.238 * * *$ \\
\hline & $(0.0981)$ & $(0.411)$ & $(0.611)$ & $(0.831)$ & $(0.455)$ \\
\hline \multicolumn{6}{|c|}{ MFI-specific controls } \\
\hline \multirow[t]{2}{*}{ age } & -0.000502 & 0.00255 & -0.0125 & -0.0125 & -0.00226 \\
\hline & $(0.000850)$ & $(0.00276)$ & $(0.0132)$ & $(0.0157)$ & $(0.0121)$ \\
\hline \multirow[t]{2}{*}{ dumshr } & $-0.0505^{* *}$ & $-0.224 * *$ & $-0.421 * *$ & $-0.602 * *$ & 0.184 \\
\hline & $(0.0199)$ & $(0.112)$ & $(0.214)$ & $(0.294)$ & $(0.245)$ \\
\hline \multirow[t]{2}{*}{ dumcoop } & $-0.0801 * * *$ & $-0.369 * *$ & $-1.133 * * *$ & $-1.245 * * *$ & $0.977 * * *$ \\
\hline & $(0.0205)$ & $(0.188)$ & $(0.231)$ & $(0.288)$ & $(0.276)$ \\
\hline \multirow[t]{2}{*}{ par30 } & $-0.552 * * *$ & $-1.144 * * *$ & -1.508 & -0.543 & 0.0887 \\
\hline & $(0.170)$ & $(0.280)$ & $(1.120)$ & $(1.257)$ & $(0.697)$ \\
\hline \multirow[t]{2}{*}{ ln_size } & -0.00147 & 0.00376 & $0.942 * * *$ & $1.007 * * *$ & $0.161 * * *$ \\
\hline & $(0.00628)$ & $(0.0242)$ & $(0.0642)$ & $(0.0622)$ & $(0.0380)$ \\
\hline \multirow[t]{2}{*}{ debt_eq } & $-0.00263 * * *$ & $-0.00796 * * *$ & 0.00724 & $0.00661 * *$ & -0.000972 \\
\hline & $(0.000954)$ & $(0.00190)$ & $(0.00455)$ & $(0.00333)$ & $(0.00106)$ \\
\hline \multirow[t]{2}{*}{ op_eff } & $-0.377 * * *$ & $-0.825 * * *$ & -0.130 & 0.103 & -0.314 \\
\hline & $(0.104)$ & $(0.236)$ & $(0.279)$ & $(0.329)$ & $(0.220)$ \\
\hline \multirow[t]{2}{*}{ glp_ta } & -0.0148 & 0.0345 & $0.715 * * *$ & $0.777 * * *$ & $0.299 * * *$ \\
\hline & $(0.0245)$ & $(0.0509)$ & $(0.187)$ & $(0.195)$ & $(0.0700)$ \\
\hline \multicolumn{6}{|c|}{ Formal institution controls } \\
\hline \multirow[t]{2}{*}{ pol_stab } & 0.0252 & -0.197 & $0.265^{* *}$ & $0.473 * *$ & $-0.191 * *$ \\
\hline & $(0.0228)$ & $(0.230)$ & $(0.104)$ & $(0.231)$ & $(0.0905)$ \\
\hline \multirow[t]{2}{*}{ reg_qual } & 0.0392 & 0.0396 & $-0.453 * *$ & $-0.762 * *$ & 0.235 \\
\hline & $(0.0490)$ & $(0.122)$ & $(0.191)$ & $(0.313)$ & $(0.143)$ \\
\hline
\end{tabular}




\begin{tabular}{|c|c|c|c|c|c|}
\hline dumlegor & $\begin{array}{l}0.0203 \\
(0.0674)\end{array}$ & $\begin{array}{l}0.0506 \\
(0.211)\end{array}$ & $\begin{array}{l}-0.554 \\
(0.622)\end{array}$ & $\begin{array}{l}0.338 \\
(0.800)\end{array}$ & $\begin{array}{l}0.256 \\
(0.520)\end{array}$ \\
\hline \multirow[t]{2}{*}{ tstart_bus } & 0.000118 & 0.00432 & 0.00479 & 0.00437 & -0.00191 \\
\hline & $(0.000532)$ & $(0.00280)$ & $(0.00379)$ & $(0.00427)$ & $(0.00254)$ \\
\hline tc_enforce & $\begin{array}{l}-7.01 \mathrm{e}-05 \\
(0.000152)\end{array}$ & $\begin{array}{l}-0.00102 \\
(0.000622)\end{array}$ & $\begin{array}{l}-0.00500 * * * \\
(0.000969)\end{array}$ & $\begin{array}{l}-0.00502 * * * \\
(0.00115)\end{array}$ & $\begin{array}{l}0.00372 * * * \\
(0.000614)\end{array}$ \\
\hline \multicolumn{6}{|c|}{ Macroeconomic controls } \\
\hline lngdppc & $\begin{array}{l}0.103 * * \\
(0.0482)\end{array}$ & $\begin{array}{l}0.124 \\
(0.120)\end{array}$ & $\begin{array}{l}-0.321^{*} \\
(0.176)\end{array}$ & $\begin{array}{l}0.151 \\
(0.270)\end{array}$ & $\begin{array}{l}0.342 * * \\
(0.150)\end{array}$ \\
\hline mft_gdp & $\begin{array}{l}0.469 \\
(0.825)\end{array}$ & $\begin{array}{l}-5.268 \\
(6.951)\end{array}$ & $\begin{array}{l}-2.987 \\
(3.776)\end{array}$ & $\begin{array}{l}-6.582 \\
(4.363)\end{array}$ & $\begin{array}{l}0.278 \\
(3.084)\end{array}$ \\
\hline infl & $\begin{array}{l}0.209 \\
(0.152)\end{array}$ & $\begin{array}{l}-0.00887 \\
(0.477)\end{array}$ & $\begin{array}{l}3.096 * * * \\
(0.687)\end{array}$ & $\begin{array}{l}4.755 * * * \\
(1.037)\end{array}$ & $\begin{array}{l}-2.096 * * * \\
(0.476)\end{array}$ \\
\hline domcrpvt_gdp & $\begin{array}{l}-0.0405 \\
(0.183)\end{array}$ & $\begin{array}{l}-0.00264 \\
(0.522)\end{array}$ & $\begin{array}{l}1.424 * * \\
(0.670)\end{array}$ & $\begin{array}{l}1.165 \\
(0.767)\end{array}$ & $\begin{array}{l}-1.047 * * \\
(0.491)\end{array}$ \\
\hline fdi_gdp & $\begin{array}{l}-0.00328 \\
(0.952)\end{array}$ & $\begin{array}{l}-4.562^{*} \\
(2.743)\end{array}$ & $\begin{array}{l}-4.483 \\
(2.976)\end{array}$ & $\begin{array}{l}-4.397 \\
(3.452)\end{array}$ & $\begin{array}{l}3.662 * \\
(2.225)\end{array}$ \\
\hline acct_own & $\begin{array}{l}-0.0491 \\
(0.0467)\end{array}$ & $\begin{array}{l}-0.0174 \\
(0.148)\end{array}$ & $\begin{array}{l}-0.302 \\
(0.322)\end{array}$ & $\begin{array}{l}-0.919 * \\
(0.539)\end{array}$ & $\begin{array}{l}-0.0636 \\
(0.265)\end{array}$ \\
\hline Constant & $\begin{array}{l}-0.574 \\
(1.522)\end{array}$ & $\begin{array}{l}9.258^{*} \\
(5.366)\end{array}$ & $\begin{array}{l}52.30 * * * \\
(9.090)\end{array}$ & $\begin{array}{l}46.51 * * * \\
(11.31)\end{array}$ & $\begin{array}{l}-48.91 \text { *** } \\
(8.151)\end{array}$ \\
\hline \multicolumn{6}{|l|}{ Statistics } \\
\hline Observations & 353 & 355 & 353 & 341 & 353 \\
\hline Groups & 71 & 71 & 71 & 71 & 71 \\
\hline R-squared: within & 0.4874 & 0.1357 & 0.7556 & 0.6163 & 0.4558 \\
\hline between & 0.6821 & 0.5716 & 0.9171 & 0.8853 & 0.8059 \\
\hline overall & 0.5808 & 0.3833 & 0.9097 & 0.8813 & 0.7975 \\
\hline Wald $\chi^{2}$ & 222.56 & 729.52 & 4709.56 & 2480.48 & 1215.30 \\
\hline
\end{tabular}

Notes: $* * *, * *$, and $*$ represent statistical significance at $1 \%, 5 \%$ and $10 \%$ levels respectively. The figures in parentheses represent Standard errors (SE). Regression results for the effect of culture on financial and social performance of MFIs are reported in this table. The first two models represent financial performance, while the last three represent social performance measures. In all models, controls are made for MFI-specific, formal institutional framework, and macroeconomic environment variables.

Again, regression results are largely consistent with those obtained in the Hofstede regressions. The strong explanatory power of culture on social performance of MFIs found earlier is again proven here. The coefficients on the power distance and assertiveness (equivalence of masculinity in Hofstede) measures conform to the hypothesis in this research and the findings in the initial regression using Hofstede's dataset. Thus MFIs achieve higher social performance in high power distance and more assertive or masculine cultures. The coefficients on the uncertainty avoidance measure across all social performance measures conform to those hypothesised in this study, though earlier regressions using Hofstede's dimensions prove inconclusive. MFIs thus achieve on the basis of these results, better social performance in high uncertainty avoidance cultures. These findings are consistent with those of Manos \& Tsytrinbaum (2014), whose analysis is done using the GLOBE dataset. A more surprising result 
however obtains for the future orientation measure (equivalence of long term orientation in Hofstede). MFIs are proven here to achieve lower social performance in more future oriented cultures, in sharp contrast to earlier findings using Hofstede's dimensions, and the findings of Manos \& Tsytrinbaum (2014) using GLOBE measures. The reasoning here may be that in more future oriented societies, people are ready to take upon bigger risks and create larger enterprises, whose often bigger financial needs are better met by commercial banks. The client base for MFIs is thus greatly reduced, explaining the negative coefficients for this variable on the social performance measures. Meanwhile Microfinance achieves high social performance in more humane- and high performance-oriented societies. In the former, public policies are more inclusive thus giving greater room for vulnerable groups to participate in the economic affairs of their respective societies. In the latter, a more competitive scenario results people being performance-driven, implying more enterprise creation and generally more risk taking. In the case of gender egalitarianism, a high measure on this variable implies potentially lower inequality, as women and vulnerable groups are presented with the same employment and business opportunities as men. Microfinance will thus achieve lower social performance in such settings. Finally, higher institutional collectivism implies institutions reward collective action thus suggesting higher social capital and a potentially higher reliance on informal finance mechanisms. Thus while empirical evidence, including earlier findings in this study suggest that more clients can be reached in more collectivist cultures due to the applicability of soft information to reduce information asymmetry and use of the group lending methodology, this may not always be the case. In fact higher collectivism may just translate to higher development and advanced use of informal finance mechanisms like Accumulated Savings and Credit Associations (ASCAs) and Rotating Savings and Credit Associations (ROSCAs). Thus the findings on the effect of the individualism/collectivism culture dimension of Hofstede on MFI performance are inconclusive as they remain subject to a number of factors among which is the level of development of informal finance in developing settings. As indicated earlier, being more collectivist does not directly translate to a higher likelihood for group loans as collectivism breeds lower societal trust, and generally makes people less economically and socially mobile. The moderating effect of informal finance on MFI performance in different cultural contexts presents a gap in the literature which warrants further attention.

\section{Conclusion}

Using all six Hofstede's cultural value dimensions - power distance, individualism/collectivism, masculinity/femininity, uncertainty avoidance, long-term orientation, and indulgence - to proxy for country level cultural values, I investigate how Microfinance financial and social performance are affected by national cultural values. Based on a sample of 111 Microfinance institutions from 21 countries, I find that culture does indeed affect the performance of MFIs, with a stronger explanatory power of the culture variable on social performance measures. Precisely, Microfinance achieves high financial and social performance in high power distance cultures, where a potentially larger Microfinance client base is present due to higher inequality and less innovation due to conformity with rules, resulting in the creation of often small enterprises which MFI-services are tailored to. Conditional upon the level of transaction costs or 
strength of formal institutions, Microfinance may additionally achieve high financial performance in cultures where bigger loans can be granted as is the case with individualistic and indulgent cultures. On the other hand, Microfinance achieves higher social performance in cultures more prone to inequality, like masculine cultures, or those with higher social capital like collectivist cultures. Long term oriented cultures are usually more inclusive in their policies thus reducing the potential client base of Microfinance clients. Social performance is thus lower in long term oriented cultures, and depending on the level of transaction costs, MFIs again can reach huge financial targets due to potentially bigger loans to these long-term oriented clients who are more prone to taking risks, investing, and creating bigger enterprises. These findings, obtained using a random effects estimator are robust to the use of an alternative set of culture measures. The findings are important and should be of interest to social or impact investors with vast investment or potential investment outlays spread across the developing world when deciding where and how much to invest based on fund objectives, global development partners when designing poverty-reduction strategies especially those which go through microcredit schemes, and researchers who have till date paid inadequate attention to the moderating effects of culture on a number of economic outcomes relating to poverty, and development as a whole.

\section{References}

Aggarwal R., Goodell J. W., \& Selleck L. J. (2015), Lending to Women in Microfinance: Influence of Social Trust and National Culture, International Business Review 24, pp. 55-65

Ahlin C., Lin J. \& Maio M. (2011), Where does Microfinance Flourish? Microfinance Institution Performance in Macroeconomic Context, Journal of Development Economics 95, pp. 105-120

Alesina A., Devleeschauwer A., Easterly W., Kurlat S., \& Wacziarg R. (2003), Fractionalization, Journal of Economic Growth 8(2), pp. 155-194

Ashraf B. N., Zheng C., Arshad S. (2016), Effects of national culture on bank risk-taking behavior, Research in International Business and Finance 37, pp. $309-326$

Berggren O., \& Burzynska K. (2014), The Impact of Social Beliefs on Microfinance Performance, Knut Wicksell Working Paper 5

Beugelsdijk S., Maseland R., \& Van Hoorn A. (2015), Are scores on Hofstede's Dimensions of National Culture stable over time? A cohort analysis, Global strategy Journal 5, pp. 223 - 240

Bjørnskov C. (2008), Social Trust and Fractionalization: A Possible Reinterpretation, European Sociological Review 24(3), pp. 271-283

Chen K. M. (2013), The Effect of Language on Economic Behavior: Evidence from Savings Rates, Health Behaviors, and Retirement Assets, American Economic Review 103(2), pp. 690-731

Dutta N. \& Mukherjee D. (2011), Is culture a determinant of financial development?, Applied Economics Letters 19(6), pp. 585-590

Elkhuizen L., Hermes N., Jacobs J. \& Meesters A. (2018), Financial development, financial liberalization and social capital, Applied Economics 50(11), pp. 1268-1288 
Epstein M.J. \& Yuthas K. (2011), The critical role of trust in microfinance success: Identifying problems and solutions, Journal of Developmental Entrepreneurship 16 (4), pp. 477-497

Guiso L., Sapienza P., \& Zingales L. (2006), Does culture affect economic outcomes?, Journal of Economic Perspectives 20(2), pp. 23-48

Hofstede G., Hofstede G. J., \& Minkov M. (2010), Culture and organisations: software of the mind, McGraw-Hill, $3^{\text {rd }}$ edition

Hofstede G. (2011), Dimensionalizing Cultures: The Hofstede Model in Context, Online Readings in Psychology and Culture, 2(1)

Hofstede G. (1983), The Cultural Relativity of Organizational Practices and Theories, Journal of International Business Studies 14, pp. 75-89

House R.J., Hanges P. J., Javidan M., Dorfman P. W., \& Gupta V. (2004), Culture, Leadership, and Organizations: The GLOBE Study of 62 Societies, Thousand Oaks, Sage

Huff L. \& Kelley L. (2005), Is collectivism a liability? The impact of culture on organizational trust and customer orientation: a seven-nation study, Journal of Business Research 58, pp. 96 - 102

La Porta R., Lopez-de-Salanes F., Shleifer A., \& Vishny R. (1999), The Quality of Government, Journal of Law, Economics, and Organization 15(1), pp. 222-279

Licht A., Goldschmidt C., \& Schwartz S. (2007), Culture rules: The foundations for the rule of law and other norms of governance, Journal of Comparative Economics 35(4), pp. 659-688

Manos R. \& Tsytrinbaum L. (2014), Determinants of Performance in the Microfinance Industry: The Role of Culture, in R. Mersland \& Ø. Strøm (Eds.), Microfinance institutions: Financial and social performance (pp. 53-78). Palgrave McMillan: Basingstoke

Masanjala W. H. (2002), Can the Grameen Bank Be Replicated in Africa? Evidence from Malawi, Canadian Journal of Development Studies 23(1), pp. 87-103

Mersland R., D'Espallier B., \& Supphellen M. (2013), The Effects of Religion on Development Efforts: Evidence from the Microfinance Industry and a Research Agenda, World Development 41, pp. 145-156

Mihet R. (2012), Effects of Culture on Firm Risk-Taking: A Cross-Country and Cross-Industry Analysis, IMP WP WP/12/210

North D. C. (1992), Transaction Costs, Institutions, and Economic Performance, International Center for Economic Growth Occasional papers 20, pp. 5 - 32

Postelnicu L. \& Hermes N. (2015), Microfinance Performance and Informal Institutions: A Cross-country Analysis, ULB CEB Working Paper $N^{\circ} 15 / 032$

Spolaore E., \& Wacziarg R. (2009), The diffusion of development, Quarterly Journal of Economicss 124(2), pp. 469-529.

Stulz R. M., Williamson R. (2003), Culture, openness, and finance, Journal of Financial Economics 70, pp. 313-349 


\section{$3^{\text {rd }}$ International Conference on BUSINESS, MANAGEMENT \& ECONOMICS}

Sundeen L. \& Johnson D.K. (2012), "It's not what you know, it's who knows what you know: An econometric analysis of the effectiveness of microfinance in the presence of endogenous peer effects", Unpublished working paper

Vanroose A. \& D'Espallier B. (2013), Do microfinance institutions accomplish their mission? Evidence from the relationship between traditional financial sector development and microfinance institutions' outreach and performance, Applied Economics 45(15), pp. 1965-1982

Williamson O. E. (2000), The New Institutional Economics: Taking Stock, Looking Ahead, Journal of Economic Literature 38(3), pp. 595-613 